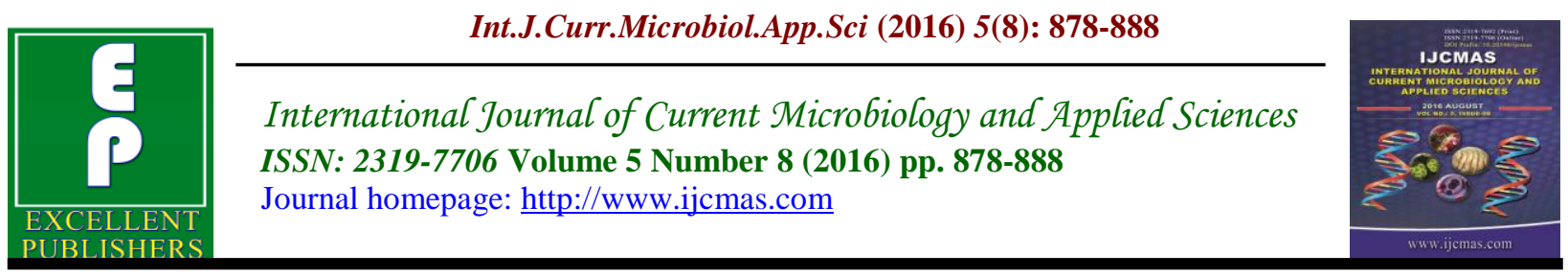

Original Research Article

http://dx.doi.org/10.20546/ijcmas.2016.508.099

\title{
Development of Protein-based Biodegradable Films from Fish Processing Waste
}

\author{
Raj Kamal Gautam*, Aarti S. Kakatkar and Manisha N. Karani \\ Food Technology Division, Bhabha Atomic Research Centre, Trombay, Mumbai, India \\ *Corresponding author
}

\section{A B S T R A C T}

\section{Keywords}

Fish processing waste; protein; Antibiotics; Biodegradable film; Packaging.

\section{Article Info}

Accepted:

28 July 2016

Available Online:

10 August 2016
Biodegradable films prepared using muscle protein from fish waste and processing discard (FG), fish gel with potato starch (FGS), fish gel with butylated hydroxy toluene (FGB) and Fish Gel with ascorbic acid (FGA) were of thickness ranging from 0.08 to $0.09 \mathrm{~mm}$. These films were analysed for their physical, mechanical, and barrier properties. FGA had significantly higher elasticity (126.21\%), and tensile strength $(1.19 \mathrm{MPa})$ with lower water vapour permeability $(0.3940 \pm 0.0051$ $\mathrm{g} / \mathrm{cm}^{2} /$ day), oxygen permeability $\left(174 \mathrm{ml} / \mathrm{m}^{2}\right.$ xday) and water solubility $(12.18 \%)$. Therefore, FGA had better tensile strength, lower barrier properties and less water solubility compared to FG, FGS and FGB. Mechanical properties of this film were similar to the films prepared from other biological origins. The result indicated that the biodegradable film from fish waste and processing discard muscle protein with ascorbic acid as antioxidant was suitable for application in food packaging.

\section{Introduction}

Commercially available synthetic plastic packaging material, which has detrimental effects to our health and environment, is now being replaced by edible non-toxic and biodegradable packaging materials (GómezEstaca et al., 2009). Bio-based polymeric films for food packaging application have drawn the attention of researchers as an alternative approach to deal with the problem of disposal of plastic materials (Muppalla et al., 2014). Biodegradable films are eco-friendly, non-toxic with comparable physical and chemical properties to synthetic polymeric films. Natural biopolymers like protein, polysaccharides, lipids or their combination can be utilised for preparation of biodegradable films (Tongnuanchan et al., 2012).

Edible films may be wrapped, coated or sprayed over foods. These films act as selective barrier against the transmission of gases, vapours, and solutes which improves food quality, extend shelf life and provide physical protection (Zhong and Xia, 2007; Sothornvit and Krochta, 2001). It is an age old practice to apply edible films and coatings like waxes, oils, resins, sucrose, fatty acid to prevent desiccation and enhance shelf life of fresh fruits and vegetables (Kester and Fennema, 1986; Baldwin, 1994). 
Plant and animal based protein films are developed using their gel forming ability (Cuqet al., 1995; Venugopal, 1997; Jang et al., 2011; Pires et al., 2011; Hanani et al., 2013). Amongst them, fish proteins have been investigated for the development of edible and biodegradable film. These films have functional properties and ability to carry functional components like antioxidants, vitamins, flavours and colouring agents (Kester and Fennema, 1986; Krochta and De Mulder-Johnston, 1997; Appendini and Hotchkiss, 2002). The world marine capture fisheries contribute more than $50 \%$ of the total world fish production. About $70 \%$ of fish is processed before final sale, resulting in $20-30 \%$ of fish waste depending on the level of processing and type of fish (Ghaly et al., 2013). Processing of fish generates enormous amounts of waste, for e.g. processing of shrimp products generates almost $50 \%$ of waste, while in case of fish fillets $75 \%$ of the total fish weight accounts for fish waste. Utilization of fish waste helps to eliminate harmful environmental aspects and improve quality of fish processing. Fish processing waste can be useful in development of various important industrial and medical byproducts as well as non-toxic and biodegradable film. The utilization of fish waste helps in generation of additional revenue and also reduces disposal costs of safe waste disposal, together with providing cleaner environment (Mathew, 2014). Major demerits of biodegradable films, especially protein films, are fragility of the material, higher water solubility and reduced water vapour permeability (WVP). This has been overcome by the use of plasticizers such as glycerol and sorbitol while making the film. Flexibility of the films can be improved with the use hydrophilic plasticizers (Cuq et al., 1997; Yang and Paulson, 2000; Sobral et al., 2001; Müller et al., 2009).

For many years, research has been carried out to enhance the shelf life of fresh and frozen foods by developing environmental friendly biodegradable and edible packaging films and coatings (Aristippos and Curtis, 1990). However, there are very few studies reported on fish protein based biodegradable films and coatings. Therefore aim of the present work was to develop a biodegradable film using fish processing waste and discards and to characterize their mechanical and barrier properties, comparison of changes in mechanical and barrier properties on incorporation of soluble starch and antioxidants like Butylated hydroxy toluene (BHT) and ascorbic acid during storage at ambient temperature.

\section{Materials and Methods}

\section{Materials}

Fish waste and processing discard was collected from local fish processing centres and fish markets. Fish meat was separated using meat bone separator.

Glycerol, glacial acetic acid and extra pure AR soluble potato starch was procured by SRL Pvt. Ltd Mumbai, India. BHT and ascorbic acid were supplied from Hi Media Laboratories Pvt. Ltd. Mumbai, India.

\section{Preparation of the film}

Fish gel was prepared as method described by Kakatkar (2004) using fish meat obtained from fish waste and processing discards. Gel was homogenised with water containing $3 \%$ (v/v) glycerol and $0.75 \%(\mathrm{v} / \mathrm{v})$ glacial acetic acid in the ratio $1: 1.5$ to yield protein dispersion. Starch gel (20 \% w/v) was prepared using soluble potato starch extra pure AR. Starch along with water was heated in microwave to yield a viscous gel. Different types of fish gel dispersion were 
prepared using various combinations and proportions of starch gel, antioxidants like BHT, ascorbic acid. Dispersion containing fish gel : starch gel in varying (100:0, 90:10, 80:20, 70:30, 60:40, 50:50, 40:60, 30:70, 20:80 and $0: 100, \mathrm{w} / \mathrm{w}$ ) proportion, fish gel dispersion containing BHT $(0.005 \%)$ and fish gel dispersion with $0.005 \%$ ascorbic acid were prepared. Fish gel film with $(80: 20$ ratio or $20 \%$ w/v) was better with respect to tensile strength and elongation at break. Increase in starch proportion resulted in film with very low elongation at break and were brittle than fish film with $20 \% \mathrm{w} / \mathrm{v}$ starch.

All the films were blended by using homogenizer (Polytron PT 3100, Kinematica, Switzerland) at room temperature for $3 \mathrm{~min}$ and degassed. Fish films were prepared by casting method as described by Rao et al. (2010). The films were prepared by pouring $200 \mathrm{ml}$ of dispersions on Teflon plates $(20 \times 20 \mathrm{~cm})$. The films were dried at $60{ }^{\circ} \mathrm{C}$ in humidity chamber (Model FX 1077, Jeiotech Co., Ltd., China) at $50 \%$ relative humidity $(\mathrm{RH})$ to obtain films with uniform thickness. Film characteristics were determined after all films were preconditioned in a constant temperature humidity chamber set at $23{ }^{\circ} \mathrm{C}$ with $50 \% \mathrm{RH}$ for $24 \mathrm{~h}$.

\section{Physical and mechanical properties}

\section{Determination of film thickness}

Thickness of the films (mm) was measured with a precise digital micrometer (Mitutoyo Manufacturing Co. Ltd., Japan) to the nearest $0.0001 \mathrm{~mm}( \pm 5 \%)$ at five random locations on the film. Mean thickness value for each film was calculated.

Measurement of tensile strength (TS) and elongation at break (ELB)

Tensile strength (TS) and Elongation at break (ELB) were measured according to
ASTM method D 882-00 (ASTM, 2001) using TA-HD plus texture analyser (Stable Micro Systems, Surrey, UK). The film strip of dimension $50 \mathrm{~mm}$ length $\mathrm{x} 15 \mathrm{~mm}$ width was attached between the grips of the texture analyser. Initial grip separation $\left(\mathrm{L}_{1}\right)$ and cross-head speed were set at $50 \mathrm{~mm}$ and $5.0 \mathrm{~mm} / \mathrm{s}$, respectively. TS of the films were expressed in MPa and calculated by dividing the maximum load $(\mathrm{N})$ by cross-sectional area $\left(\mathrm{m}^{2}\right)$. It was moved at speed of 500 $\mathrm{mm} / \mathrm{min}$ and break load range adjustment of $500 \mathrm{~N}$. The break load and elongation at break were measured during test. The Tensile strength at break was calculated in $\mathrm{kg} / \mathrm{cm}^{2}$ from the original cross-sectional area. The mean of 3 values was used for TS and ELB calculation.

Area of cross-section $=$ width $\mathrm{x}$ thickness in $\mathrm{cm}$.

Elongation at break is expressed as percentage change of the initial length between the reference lines. The mean of triplicate results is calculated for estimation of \%ELB.

$\% \mathrm{ELB}=\left(\mathrm{L}_{2}-\mathrm{L}_{1}\right) / \mathrm{L}_{1} \times 100$

Where

$\mathrm{L}_{1}=$ initial length

$\mathrm{L}_{2}=$ final length at the time of break

\section{Barrier properties of the fish film}

Measurement of water vapour transmission rate (WVTR) and oxygen transmission rate (OTR)

Water vapour transmission rate (WVTR) of the films was measured by an automatic water vapour permeability testing machine L80-5000 (PBI Dansensor, Denmark) at $37^{\circ} \mathrm{C}$ and $10 / 15 \%$ RH. This instrument works on the principle on standard test 
methods for water vapour transmission of materials (ASTM E96/E96M-05). The measuring range of the instrument was 0.03 $10,000 \mathrm{~g} / \mathrm{m}^{2} /$ day. WVTR of films was measured using aluminium sample cards (reduction to 5\% area) and oxygen transmission rate (OTR) of the film at $23 \mathrm{C}$ and $0 \% \mathrm{RH}$ was measured using automatic oxygen permeability testing machine L80 5000 (PBI Dansensor, Denmark). The measuring range of the instrument was 0.1 $10,000 \mathrm{~cm}^{3} / \mathrm{m}^{2} /$ day. OP of the films was measured by placing samples in the sample holder having an exposed area of $50 \mathrm{~cm}^{2}$.

\section{Measurement of water solubility of film}

Modified method described by Bourtoom 2006 was used to measure solubility of film in water. The water solubility can be described by the amount of dry matter content solubilised after a $24 \mathrm{~h}$ of immersion of film in water. The initial content of dry matter of films was calculated by drying to constant weight in hot air dryer at $60{ }^{\circ} \mathrm{C}$. Circular pieces of film of about $2 \mathrm{~cm}$ radius, precisely weighed to the nearest $0.0001 \mathrm{~g}$ for the initial dry mass. These cut pieces of films were immersed in to $50 \mathrm{ml}$ distilled water containing $0.02 \% \mathrm{w} / \mathrm{v}$ sodium azide to inhibit microbial growth. To calculate film solubility in water (\%), the remaining amount of dry matter after one day of immersion of films in water at ambient temperature with occasional stirring was calculated.

The pieces of the films not solubilised in water, were dried to constant weight in a hot air dryer at $104{ }^{\circ} \mathrm{C}$,. Mean of 6 values were used to calculate percentage solubility of each film. Difference in initial dry matter mass and final dry matter mass used to calculate total soluble matter using following equation:
$\%$ Film Solubility $=\underline{\text { (dry matter mass of film }}$ before test- dry matter mass of film after test) $\mathrm{x} 100$

Dry matter mass of film before test

\section{Determination of colour}

Colour of the film was measured according to method described by Pires 2011 using Minolta CM-3600d Spectrophotometer (Konica Minolta Sensing, Inc, Osaka, Japan). The whole visible spectrum (360 to $780 \mathrm{~nm})$ was recorded with $\Delta \lambda=10 \mathrm{~nm}$ and considering illuminant $\mathrm{D}_{65}$ and $10^{\circ}$ observer as references.

The CIELAB parameters, $L^{*}$ (lightness), the chromaticness coordinates, a* (+red to green component), and $b^{*}$ (+yellow to -blue component) were analysed by JAYPAK software (Quality Control System, Version 1.2). Means of hunter $L^{*}, a^{*}$, and $b^{*}$ values were determined after taking average of 3 colour value parameters across each film, and the difference in colour components during storage were analysed statistically by using one-way analysis of variance (ANOVA).

\section{Storage study of the films}

Changes in mechanical, barrier and water solubility rate of films were studied for 4 months at ambient temperature to evaluate the stability of the films during storage.

\section{Statistical analysis}

All experiments were carried out in triplicate and the mean values with standard deviation were reported. Significant difference between the means of variables was calculated by one-way analysis of variance (ANOVA) using OriginLab ${ }^{\mathrm{TM}}$ software version 6.1 Corporation, Northampton, MA 
01060, USA). A statistical difference at $\mathrm{p}<$ 0.05 was considered to be significant.

\section{Results and Discussion}

\section{Physical and mechanical properties}

\section{Determination of film thickness}

The thickness of the FG (film with fish gel), FGS (film with fish gel and starch), FGB (film with fish gel and BHT) and FGA (film with fish gel and ascorbic acid) were $0.08 \pm$ $0.01,0.09 \pm 0.01,0.08 \pm 0.01$, and $0.08 \pm$ $0.01 \mathrm{~mm}$ respectively. There was no significant difference in thickness amongst the films. The thickness of the films was comparable to earlier reports with average thickness of the films from fish proteins ranging from 0.08 to $0.13 \mathrm{~mm}$. (Paschoalick, 2003; Kolodziejska and Piotrowska, 2007; Ninan, 2010).

Measurement of tensile strength (TS) and elongation at break (ELB)

Mean TS of FG, FGS (80:20), FGB and FGA ranged from $8.3 \pm 0.03$ to $14.7 \pm 0.21$ MPa (Fig. 1a). Mean ELB of FG, FGS (80:20), FGB and FGA ranged $114.10 \pm$ 0.28 to $126.21 \pm 0.39(\%)$ respectively (Fig.1b). FGA had maximum ELB (126.21\%), and TS (1.19 MPa), While FGS resulted in highest TS (1.47 MPa), and ELB $(108 \%)$. The mechanical properties showed that FGA films were better than FGS, FGB and FG.

There were no significant changes in physical properties of films during storage at ambient temperature over a period of 4 months. Similar edible and biodegradable packaging films based on fish myofibrillar proteins have shown TS of 17.1 MPa, ELB of $22.7 \%$, at a thickness of $0.034 \mathrm{~mm}$ (Cuq et al., 1995). Kaewprachu and Rawdkuen (2014) showed that biodegradable films from giant catfish skin gelatine showed a higher TS (26.42 MPa) and ELB (128.25\%).
A higher TS of $5.86 \mathrm{MPa}$ and $123.5 \%$ of ELB had been reported from edible films based on Alaska Pollack (Shiku et al., 2004). Variation in the data could be due to compositional differences and the procedure employed for film preparation. A fish film, which is to be used as packaging material, should have higher tensile strength along with high elongation at break point. Films prepared exclusively by starch were more fragile and with inferior elongation properties (Tapia-Blacido et al., 2005). FGA films showed better mechanical properties with higher tensile strength and elasticity than other films over a period of 4 months.

\section{Barrier properties of the film}

\section{Measurement of water vapour transmission rate (WVTR) and oxygen transmission rate (OTR)}

Barrier properties of a polymer are crucial to product-package shelf-life. The specific barrier requirement of a package system depends upon the food characteristics and the intended end-use applications (Siracusa, 2012). WVTR of the films were comparable and it ranged from $0.3862 \pm 0.0049$ to $0.4020 \pm 0.0036 \mathrm{~g} / \mathrm{cm}^{2} /$ day (Fig.1c) with no significance variation in means. The WVTR of films remained unaffected during storage for 4 month at room temperature. WVTR of fish films were comparable and found to be lower than other similar films like gelatinstarch film $\left(1.08 \pm 0.01 \mathrm{~g} / \mathrm{cm}^{2} /\right.$ day $)$, albumin-starch film $\quad(0.938 \quad \pm \quad 0.01$ $\mathrm{g} / \mathrm{cm}^{2} /$ day $)$, casein-starch film $(0.892 \pm 0.01$ $\mathrm{g} / \mathrm{cm}^{2} /$ day) as reported by Jagannath et al., (2003) and surimi based edible film (1.69 \pm $0.06 \mathrm{gm}^{-1} \mathrm{~s}^{-1} \mathrm{~Pa}^{-1}$ ) as described by Shiku et al., (2004). Films have shown varying degree of oxygen permeability, with FG resulting as impermeable of oxygen, while FGA and FGB were oxygen permeable in order of $169.4 \pm 4.7 \mathrm{ml} / \mathrm{m}^{2} \mathrm{xday}$, and $973 \pm$ $3.5 \mathrm{ml} / \mathrm{m}^{2} \mathrm{x}$ day respectively (Fig.1d). 

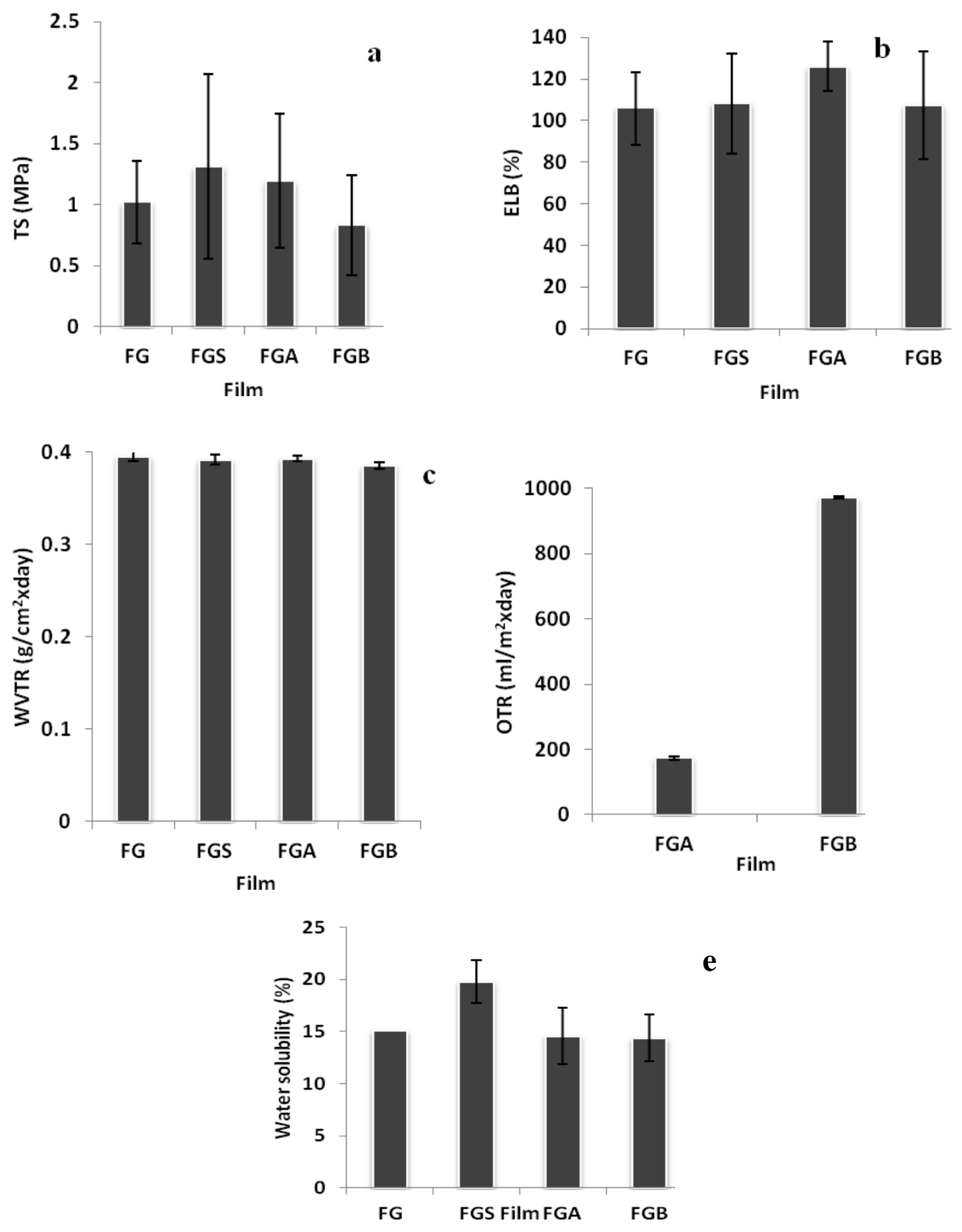

Fig.1 Physical and barrier properties of the films-Tensile strength (a), elongation at break (b), water vapor transmission rate(c), oxygen transmission rate (d) and water solubility rate (e) of the films. The results shown are mean $\pm \mathrm{SD}$ of three independent experiments. 


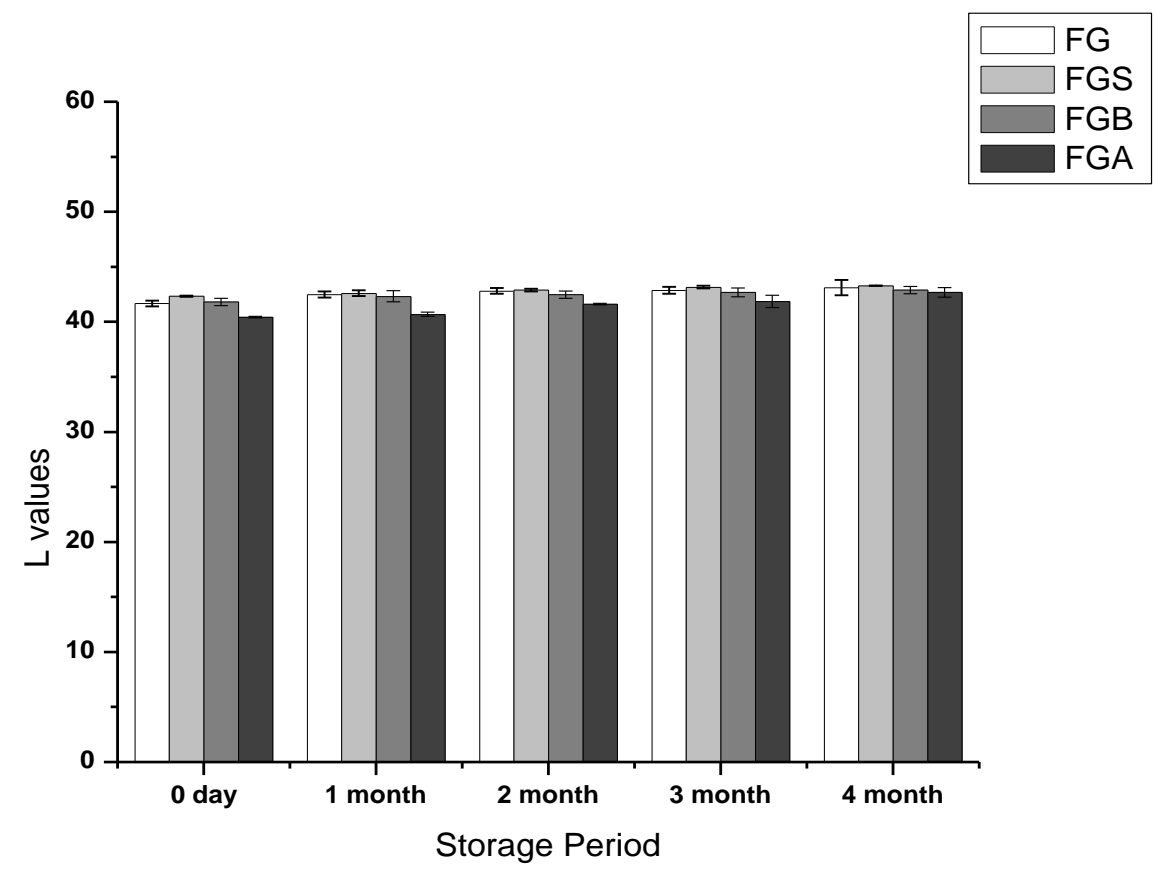

Fig. 2 Changes in $\left(L^{*}\right.$ values $)$ of the films during storage period. The results shown are mean \pm $\mathrm{SD}$ of three independent experiments.

$L^{*}$ values - lightness or clarity, which ranged from 0 (black) to 100 (colourless).

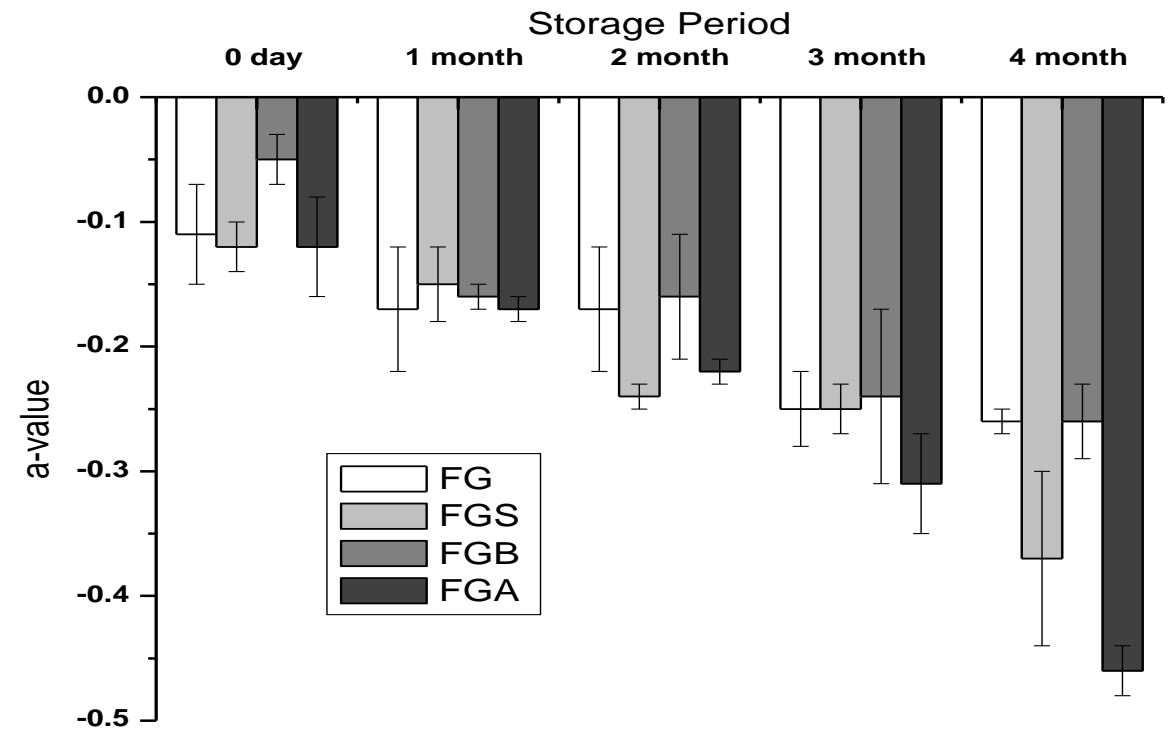

Fig.3 Changes in $a^{*}$ values of the films during storage period. The results shown are mean \pm SD of three independent experiments.

$a^{*}$ values - chromaticness co-ordinates, which ranged from red(+) to green (-) 


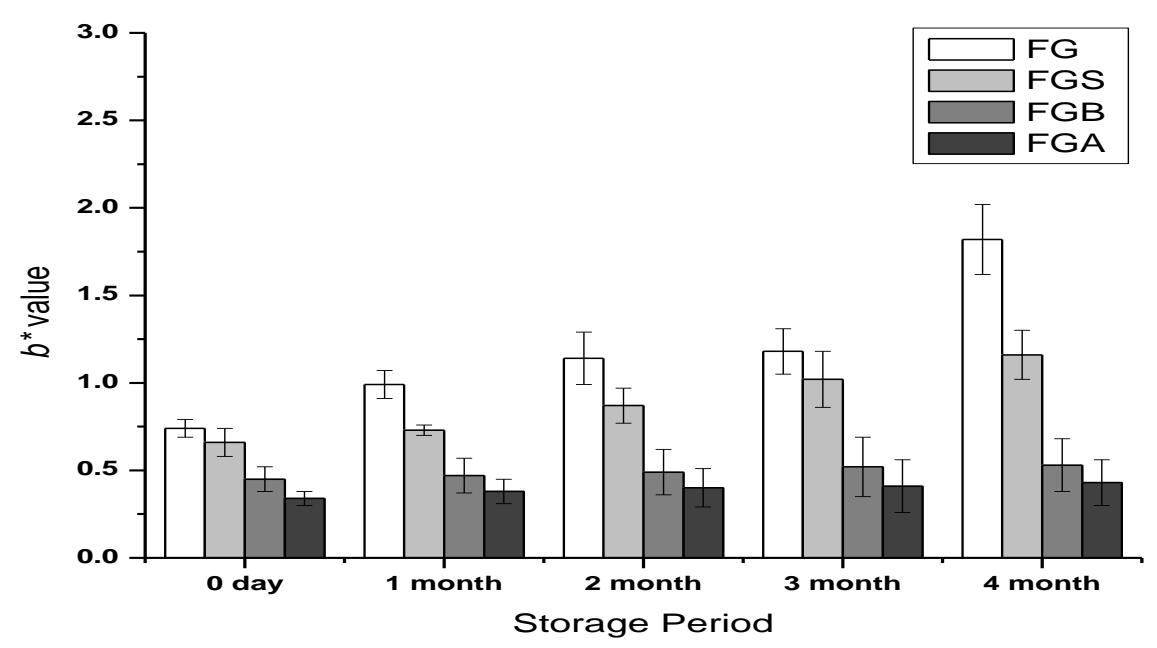

Fig.4 Changes in $b^{*}$ values of the films during storage period. The results shown are mean $\pm \mathrm{SD}$ of three independent experiments.

$b^{*}$ values - chromaticness co-ordinates, which ranged from yellow (+) to blue (-).

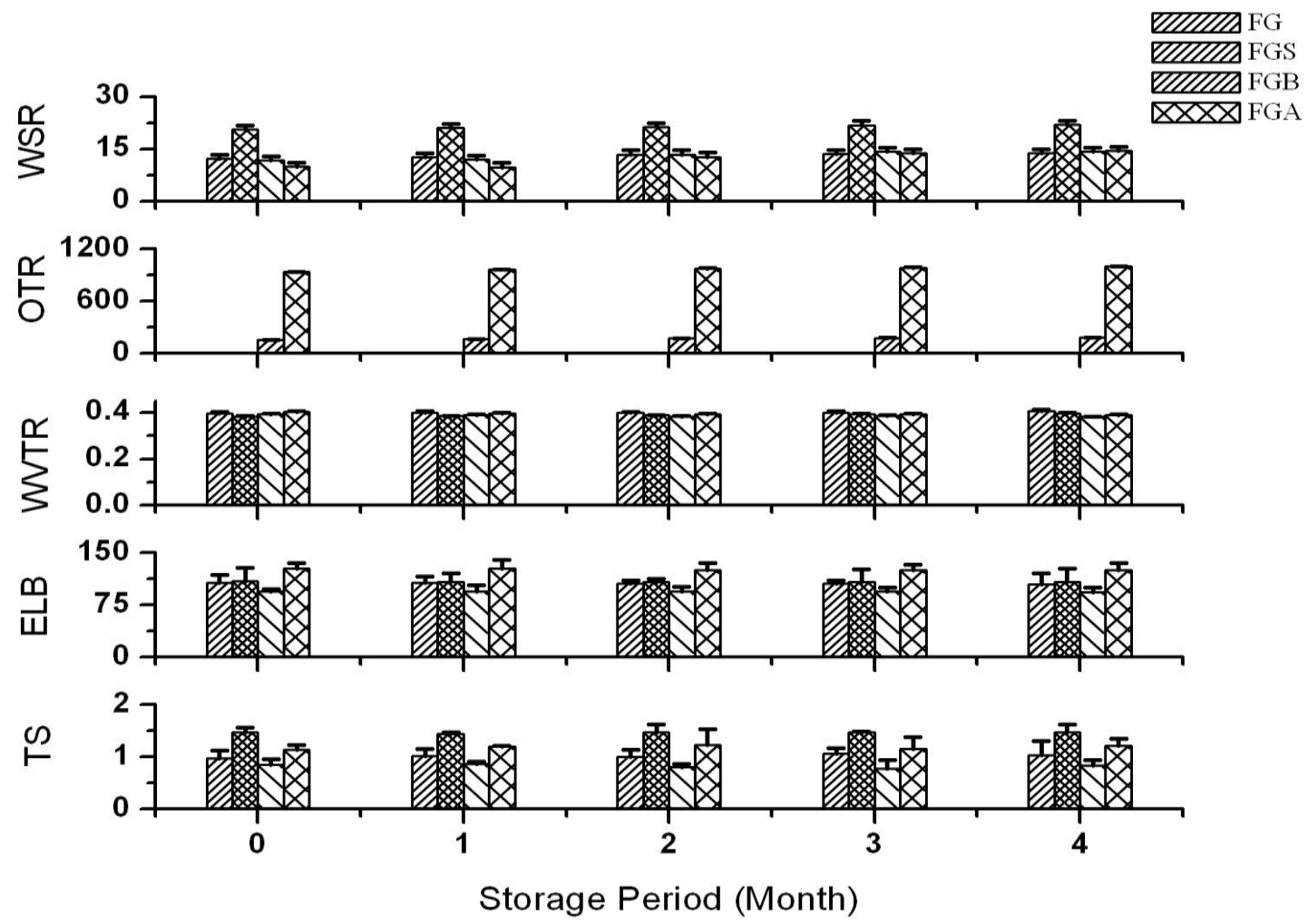

Fig.5 Changes in Tensile strength [TS (MPa)], Elongation at break [ELB (\%)], Water vapor transmission rate [WVTR $\left.\left(\mathrm{g} / \mathrm{cm}^{2} \mathrm{xday}\right)\right]$, Oxygen transmission rate [OTR $\left.\left(\mathrm{ml} / \mathrm{m}^{2} \mathrm{xday}\right)\right]$ and Water solubility rate [WSR (\%)] of the films during 4 month of storage period. The results shown are mean $\pm \mathrm{SD}$ of three independent experiments. 
Oxygen permeability of FGS film could not be measured as it became brittle and tore off while measurement. Fish films showed higher rate of oxygen transmission and compared with other reported films like, Cellulose acetate phthalate film (CAP film) and Gluten film, which showed lower oxygen permeability of $22.21 \pm 1.23 \%$ $\mathrm{ml} / \mathrm{m}^{2}$ xday and $41.02 \pm 0.86 \% \mathrm{ml} / \mathrm{m}^{2}$ xday respectively (Falchouri et al., 2004). Improving oxygen barrier performance of a film helps as oxygen promotes degradation of food by oxidation and thus affects organoleptic properties of food (Siracusa, 2012).

\section{Measurement of water solubility}

Water solubility of FG, FGA and FGB was $13.25 \pm 0.69 \%, 12.18 \pm 2.14 \%$, and 13.28 $\pm 1.20 \%$ respectively, while FGS was more water soluble with $21.48 \pm 0.52 \%$ solubility (Fig.1e). Cellulose acetate phthalate film (CAP film) and gluten film have100 \% and $22.7 \pm 4.10 \%$ water solubility (Falchouri et al., 2004).

\section{Determination of colour}

Changes in colour components for samples analyzed during storage at ambient temperature. $L^{*}$ values (lightness) of the samples did not change significantly ( $\mathrm{P}<$ 0.05) during storage over a period of 4 months (Fig. 2). There was a slight reduction in $a^{*}$ values towards greenness without any significant change $(\mathrm{P}<0.05)$ (Fig. 3).

However, there was significant difference in $b^{*}$ values of the FG and FGS films. Whereas, $b^{*}$ values of the FGB and FGA films changed insignificantly ( $\mathrm{P}<0.05)$ (Fig. 4). Films had shown a slight yellowish discoloration, which may be due to nonenzymatic browning reactions between protein components.

\section{Storage study of the films}

Results showed that films were not significantly different for different physical and barrier parameters $(\mathrm{P}<0.05)$ after 4 months of storage study at ambient temperature (Fig. 5).

In conclusion, combination of fish protein, starch and antioxidants lead to successful development of clear, flexible biodegradable films. The film with combination of ascorbic acid and fish gel (FGA) showed a better tensile strength along with higher elongation at break point as compared to FG, FGS and FGB. Thus inclusion of ascorbic acid as antioxidant has provided better proteinbased biodegradable packaging film. The study shows effective use of fish protein for preparation of environmental friendly biodegradable films, which can be used in food packaging industry. Functional properties of these biodegradable films can be improved by incorporating natural antimicrobials and antioxidants.

\section{Acknowledgements}

I thank Mrs. Vaishali V. Mahale of Food Microbiology and Seafood Technology Section, Bhabha Atomic Research Centre, Mumbai for providing technical support during entire process of research work.

\section{References}

Appendini, P., Hotchkiss, J.H. 2002. Review of antimicrobial food packaging. Innovative Food Sci. Emerg. Technol., 3: 113-126.

Aristippos, G., Curtis, L.W. 1990. Edible Films and Coatings from Wheat and Corn proteins. Food Technol., 44(10): 63-69.

ASTM D 882-00. 2001. Standard test method for tensile properties of thin plastic sheeting. Annual book of ASTM standards. Philadelphia PA: American 
Society for Testing and Materials.

ASTM E 96-95. 2005. Standard test methods for Water Vapor Transmission of Materials. Annual book of ASTM standards. Philadelphia PA: American Society for Testing and Materials.

Baldwin, E.A. 1994. Edible coatings for fresh fruits and vegetables: past, present, and future. In: Edible Coatings and Films to Improve Food Quality (Eds.) J.M. Krochta, E. A. Baldwin, M.O. NisperosCarriedo, Lancaster: Technomic publishing Co Inc. Pp. 25-64.

Bourtoom, T., Chinnan, M.S., Jantawat, P., and Sanguandekul R. 2006. Effect of selected parameters on the properties of edible film from water-soluble fish proteins in surimi wash-water. LWTFood Sci. Technol., 39, 406-19.

Cuq, B., Gontard, N., Cuq, J.L., and Guilbert, S. 1995. Edible packaging films based on fish myofibrillar proteins: Formulation and functional properties. J. Food Sci., 60, 1369-74.

Cuq, B., Gontard, N., Cuq, J.L., and Guilbert, S. 1997. Selected functional properties of fish myofibrillar protein-based films as affected by hydrophilic plasticizers. $J$. Agric. Food Chem., 45, 622-26.

Falchouri, F.M., Tanada-Palmu, P.S., and Grosso, C.R.F. 2004. Characterization of composite biofilms of wheat-gluten and cellulose acetate phthalate. Braz. J Chem. Eng., 21(2): 261-64.

Ghaly, A.E., Ramakrishnan, V. V., Brooks, M. S., and Dave, D. 2013. Fish processing wastes as potential source of proteins, amino acids and oils: a critical review. $J$. Microb. Biochem. Technol., 5, 107-129.

Gómez- Estaca, J., Montero, P., FernándezMartín, F., Almán, A., and GómezGuillén, M.C. 2009. Physical and chemical properties of oat starch films. Mat. Sci. Eng. C- Materials for Biological Applications, 29, 532-8.

Hanani, Z.A.N., Beatty, E., Ross, Y.H., Morris, M.A., and Kerry, J.P. 2013. Development and characterization of biodegradable composite films based on gelatine derived from beef, pork and fish sources. Foods, 2: 1-17; doi:10.3390/foods2010001

Jagannath, J.H., Nanjappa, C., Das Gupta, D.K., \& Bawa, A.S. 2003. Mechanical and barrier properties of edible starchprotein based films. J. Appl. Polym. Sci., 88(1): 64-71.

Jang, S.A., Lim, G.O., and Song, K.B. 2011. Preparation and mechanical properties of edible rapeseed protein films. J. Food Sci., 76, C218-23.

Kaewprachu, P., and Rawdkuen, S. 2014. Mechanical and physico-chemical properties of biodegradable protein-based films: A comparative study. Food Appl. Biosci. J., 2(1): 15-30.

Kolodziejska, I., and Piotrowska, B. 2007. The water vapour permeability, mechanical properties and solubility of fish gelatinchitosan films modified with transglutaminase or 1-ethyl-3- (3dimethylaminopropyl) carbodiimide (EDC) and plasticized with glycerol. Food Chem., 103, 295-300.

Kakatkar, A., Sherekar, S. V., and Venugopal, V. 2004. Fish Protein dispersion as a coating to prevent quality loss in processed fishery products. Fish Technol., 41, 29-36.

Kester, J.J., and Fennema, O. R. 1986. Edible films \& coatings: a review. Food Technol., 41(12), 47-59.

Krochta, J.M., and De Mulder-Johnston, C. 1997. Edible and biodegradable polymer films: challenges and opportunities. Food Technol., 51(2): 61-74.

Müller, C.M.O., Laurindo, J.B., and Yamashita, F. 2009. Effect of cellulose fibers addition on the mechanical properties and water vapour barrier of starch-based films. Food Hydrocolloid, 23, 1328-33.

Ninan, G., Joseph, J., and Abubacker, Z. 2010. Physical, mechanical, and barrier properties of carp and mammalian skin gelatine films. J. Food Sci., 75(9): E620E626.

Paschoalick, T.M., Garcia, F.T., Sobral, P.J. 
A., and Habitante, A.M.Q.B. 2003. Characterization of some functional properties of edible films based on muscle proteins of Nile Tilapia. Food Hydrocolloids, 17, 419-27.

Pires, C., Ramos, C., Teixeeira, G., Batista, I., Mendes, R., Nunes, L., and Marques, A. 2011. Characterization of biodegradable films prepared with hake protein and thyme oil. J. Food Eng., 105, 422-428.

Mathew, P.T. 2014. Fishery waste management- problems and prospects. In: Recent advances in the development of nutraceuticals, health foods and fish feed from fish and shellfish processing discard (Eds.) A. A. Zynudeen, J. Bindu, G. Ninan, C.O. Mohan, \& R. Venkateshwarlu. ICAR-Central Institute of Fisheries Technology, Cochin, Kerala, India. Pp. 11-26.

Muppalla, S. R., Kanatt, S. R., Chawla, S. P., \& Sharma, A. 2014. Carboxymethyl cellulose-polyvinyl alcohol films with clove oil for active packaging of ground chicken meat. Food Packaging and Shelf life, 2, 51-58.

Rao, M.S., Kanatt, S.R., Chawla, S.P., and Sharma, A. 2010. Chitosan and Guar gum composite films: preparation, physical, mechanical and microbial properties. Carbohydr. Polym., 82, 1243-7.

Shiku, Y., Hamaguchi, P. Y., Benjaku, S., Visessanguan, W., and Tanaka, M. 2004. Effect of surimi quality on properties of edible films based on Alaska pollack. Food Chem., 86, 493-99.

Siracusa, V. 2012. Food packaging permeability behaviour: A report- review article. Int. J. Polym. Sci., Article ID 302029, 11 pages, doi:10.1155/2012/302029

Sobral, P.J.A., Menegalli, F.C., Hubinger, M.D., and Roques, M.A. 2001. Mechanical, Water vapour barrier and thermal properties of gelatin based edible films. Food Hydrocolloids, 15, 423-32.

Sothornvit, R., and Krochta, J.M. 2001. Plasticizer effect on mechanical properties of $\beta$-lactoglobulin films. $J$. Food Engin., 50, 149-55.

Tapia-Blacido, D., Sobral, P. J., and Menegalli, F. C. 2005. Development and characterization of biofilms based on Amaranth flour (Amaranthus caudatus). J. Food Engin., 67, 215-23.

Tongnuanchan, P., Benjakul, S., and Prodpran, T. 2012. Properties and antioxidant activity of fish skin gelatine film incorporated with citrus essential oils. Food Chem. 134(3): 1571-9; doi:10.1016/j.foodchem.2012.03.094

Venugopal, V. 1997. Functionality and potential applications of thermostable water dispersions of fish meat. Trends Food Sci. Technol., 14, 39-48.

Yang, L., and Paulson, A.T. 2000. Mechanical and water vapour barrier properties of edible gellan films. Food Res. Int., 33, 563-70.

Zhong, Q.P., Xia, W.S. 2007. Physiochemical properties of edible and preservative film chitosan/cassava starch/gelatine blend plasticized with glycerol. Food Technol. Biotechnol., 46: 262-9.

\section{How to cite this article:}

Raj Kamal Gautam, Aarti S. Kakatkar and Manisha N. Karani. 2016. Development of Proteinbased Biodegradable Films from Fish Processing Waste. Int.J.Curr.Microbiol.App.Sci. 5(8): 878-888. doi: http://dx.doi.org/10.20546/ijcmas.2016.508.099 